\title{
Policy And Implementation: Land And Agrarian Reform In South Africa
}

Jason Stratton Davis, Durban University of Technology, South Africa

\begin{abstract}
In developing nations, particularly in Africa, agrarian and land reform is part of economic development. The main reason is that no country sustained a transition out of poverty without raising productivity in its agriculture sector (Timmer, 2005).
\end{abstract}

This article examines the process of balancing land and agrarian reform in the agricultural sector in South Africa, where the need for social justice has to be weighed against the potential loss of agricultural production. The process has been likened to "balancing deck chairs on the Titanic" (Davis, 1993).

In addition, the article seeks to measure the level of success achieved since 1994 and to suggest ways forward, by drawing on Brazil's experience, where the process has evolved to developing ecological citizenship and agro-ecological production.

Keywords: Land Reform; Agrarian Reform; Ecological Citizenship

\section{BACKGROUND}

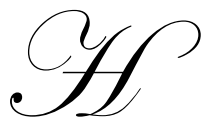

istorical evidence indicates the role agriculture plays in economic development. As Timmer (2005) points out "no country has been able to make a rapid transition out of poverty without raising the productivity in its agricultural sector". However, he notes a loss of interest in the agricultural sector starting in 1980s because of falling prices for basic agricultural commodities caused by the Green Revolution in Asia.

Evidence has emerged from Japan and Taiwan which has indicated that their rise to economic prosperity came out of surpluses generated by the agricultural sector. Research undertaken by Erh-Cheng Hwa (1983) found a significant link between industrial and agricultural growth when looking at cross-sectional data between developed and less developed countries in the periods 1960 - 1970 and $1970-1979$.

In addition, when one considers that $70 \%$ of the world's poorest and malnourished populations live trapped in subsistence agriculture and that between 35\% and 70\% of GDP of less developed countries is made up of agricultural products, then agriculture has to be an important role player in their economic development (Gemmel, 1987).

Timmer (2005) states, "After two decades of neglect, interest in agriculture is returning." Why? Agriculture is being recognised as playing an important role in reducing poverty and sustainable growth as it links the poor to growth.

Johnston-Mellor's (1961) linkages look at product markets and productive interactions by which industry and agriculture are interlinked. These forward and backward linkages between industry and agriculture are based on providing food for domestic consumption, releasing labour for industrial development, enlarging the market for domestic production, increasing the supply of domestic saving and earning foreign exchange. 
In empirical work done on the regional level, according to Meijerink and Roza (2007), the growth multipliers from agriculture exceed those from the non-agricultural sector. As a result, agriculture is now seen as an important economic driver for pro-poor growth in developing nations.

Therefore, any change caused by land and agrarian reform will directly affect the ability of agriculture to positively contribute to economic growth and poverty reduction in South Africa.

\section{CURRENT STATUS}

Thirteen percent of South Africa's land can be used for crop production; however, only $22 \%$ of this highpotential arable land has access to water. For the balance, this is a major constraint (SouthAfrica.info, 2009). This immediately indicates that any land reform process will directly affect the level of agricultural production and food security.

The economic contribution and characteristics of SA Agriculture are revealed in a report by Statistics South Africa (2009). For example, the report indicates that there was a decline in the period 1993 to 2007 in the following areas:

- $\quad$ Farming units decreased from 57980 to 39982 (2007).

- $\quad$ Farm employment fell from 1,093 265 in 1993 to 796806 in 2007 and has continued to decline.

However, there have also been improvements, such as:

- $\quad$ Gross farming income increased from R19 620180 to R79 543813.

- $\quad$ Employee remuneration climbed from R3 637620 to R8 611230.

- $\quad$ Increase in farm expenditure from R16 377145 to R 54072587.

- $\quad$ A decrease in farm debt from $78 \%$ to $46.6 \%$ (Ibid, 2009).

Over the intervening years, the overall contribution of agriculture has fallen to less than $3 \%$ with a total contribution to the value chain of approximately $11 \%$ (Ferreira, 2010). However, South Africa is among the world's top five exporters of avocados, grapefruit, tangerines, plums, pears, table grapes, and ostrich products, and in 2009, it contributed $8 \%$ to the country's total exports (Ibid 2009). This indicates that agriculture is still an important sector in the economy.

Although the economic status of agriculture in South Africa is set to prosper with improved international trade agreements with China, for example, seeking to import grains and seed oils, the "two agriculture" split remains in place and is not only constraining the sector's prosperity, but also could be a catalyst for social instability.

The Department of Agriculture's Strategic Plan 2008 states, "South Africa, with its high rate of urbanisation, racially unequal agricultural land distribution and the existence of "two agricultures"... will certainly constitute one of the most binding constraints for accelerated and shared growth in agriculture in the next 3 to 5 years" (DoA, 2008, p.10).

The successful resolution of restructuring the South African rural landscape is, therefore, a crucial component for ensuring not only stable economic development, but long-term political, social harmony and poverty reduction, especially when one considers that $47 \%$ of the South African population lives in rural areas, $76 \%$ of the poverty in South Africa is accounted for in rural areas, and that the most important source of income is social grants (Lebert, 2009).

South Africa faces the tricky task of implementing agrarian reform which will allow for economic prosperity and for social justice. At this present time, an acceptable compromise will have to be reached between the majority who are landless on the one hand and agro capital and capital minority interests on the other. This delicate and sensitive situation can be compared to the "shifting of deck chairs on the Titanic" (Davis,1993). 


\section{THE ORIGIN OF THE TWO AGRICULTURES}

The effects of apartheid ideology, in skewed resources along racial divides, can be clearly seen in the distribution of resources and incomes in the rural landscape of South Africa. The 1913 Land Act, and the 1936 Native Land and Trust Act have resulted in $87 \%$ of the land being reserved for white farmers and approximately $13 \%$ for blacks who comprise the majority of the population. Bernstein (1996) points out that the commercialisation of agriculture took South Africa along the Junker path or German route of development in which the commercial farmers were immersed in racial divisions and the use of unfree labour where, through the collaboration of the State, they managed to promote their interests. For example, further land consolidation or labour repressive legislation circumvented the labour market and hence extracted a surplus from the labourers without having to pay market wages.

The result was the development of two agricultures:

1. The black farming sector, which faced continuous undermining, had been squashed onto $13 \%$ of the land; namely, areas known as Bantustans, plagued by the following problems:

$\begin{array}{ll}\text { - } & \text { increasing population pressures } \\ \text { - } & \text { soil erosion, deteriorating soil fertility } \\ \text { - } & \text { labour intensive } \\ \text { low productivity and output. }\end{array}$

2. The white agricultural sector was (and largely still is) characterised by:

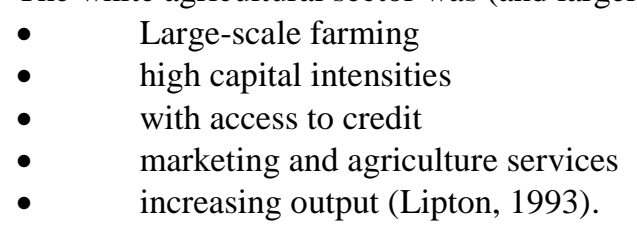

In an article entitled "South Africa's: Two agricultures?", Lipton (1977), after revising the figures of the value of output between 1950-1, discovered that the value of morgen produced by white farmers was only two to three times more than that of the black farmers, which is surprising given the enormous differentials in input and economic incentives given to each group.

Further evidence shows that $30 \%$ of white commercial farmers produced $75 \%$ of the gross farm incomes and that in 1993, an accumulation crisis was being experienced (Bernstein, 1992). This was a result of declining solvency, liquidity and profitability caused by excess government interference in the market, in the form of low interest loans and subsidisation combined with domestic inflation, and higher import costs of finished material goods leading to higher import costs (caused by oil shocks and sanctions). The net result was that South African agriculture was caught in a cost-price squeeze as the prices of inputs and production costs rose, while prices for produce lagged behind (Roth et al, 1992).

From the above facts, there is no doubt that agrarian reform still needs to take place, not only on the sole basis of a call for social justice, but also on rational economic grounds, to prevent the repetition of similar accumulation crises in the agricultural sector.

The suggested path of land and agrarian reform from 1993 was:

1. The target would be the rural impoverished and those affected by the past legislation.

2. Mobilisation of the affected communities into productive small-scale farming units via the provision of economic incentives and agricultural services.

3. Reorganisation of State subsidisation of the agricultural sector so that firstly, the emergent small-scale farming units were not disadvantaged when compared to large-scale enterprises and secondly, so that the accumulation crises being experienced in this sector were not repeated. 
4. Structuring of land reform so that the supply of raw materials and food supplies were minimally disturbed during the reconstruction phase, which could mean leaving the land of $30 \%$ of the farmers who produce $80 \%$ of the output intact whether they were large-scale enterprises or not.

5. An active state intervention and political willpower to oversee and coordinate such reforms.

6. To allow for the large-scale investment in agriculture research and development and in rural infrastructure (Davis, 1993).

All these ingredients were necessary to ensure the development of a stable and sustainable agricultural sector that would carry South Africa into the year 2000 and beyond. The World Bank and a number of South African academics, in October 1993 at a conference held by the Land and Agricultural Policy, drew up and presented guidelines for a Rural Restructuring Program (RRP). The proposal puts forth that between 10\% and 50\% of existing commercial farm land be redistributed with the aim of considerably increasing rural employment and creating a stable rural economy. The document further states that if $30 \%$ of agricultural land is redistributed, then one million rural jobs will be created. Over the five years, the cost involved to the government is 2.5 billion dollars per year (Munnik, 1993/4).

New models restructuring, like the Worker's Farmer's Equity Model where private companies, through economic incentives, could be encouraged to buy farms and slowly allow the workers to buy shares in the enterprises they will by running, which would allow the workers time to accumulate shares and income to perhaps to be able to one day collectively own the farm sharing in the total profits (McKenzie, 1993).

Another issue that should be considered when developing a Rural Development Program is that of rural diversification. This process includes the broadening and strengthening of rural incomes by introducing new crops and technologies into existing systems to develop off-farm jobs in small-scale industries (rural industrialisation like in China).

\section{MEASURING SUCCESS}

The success of land and agrarian reform in South Africa is measured against nine objectives that need to be met in order to achieve a sustainable agricultural sector. These objectives were suggested by Agrawal (1994) when considering similar land and agrarian reform initiatives. These were:

1. Promotion of incentives: Land reform needs to provide incentives that go directly to the farmers/tillers for raising production and making improvements in agricultural practices.

2. Costless methods of increasing production: Raising production without becoming capital intensive; i.e., timely ploughing, sowing, fertilisation, watering, etc. can improve and raise production.

3. The integration of agricultural development with the mainstream economy.

4. Rendering social justice and changes in the tenure system.

5. Agricultural support services and investment in agricultural research.

6. Policymaking and implementation should be consistent and clear.

7. The State should be active in agricultural development as well as the expansion of social services.

8. The State should encourage diversification within agriculture into small and medium agro-based industries to provide alternative employment and income.

9. The political and administrative capacity needs to be present for implementing this program of reform (Agrawal, 1994).

\section{PERFORMANCE SO FAR}

When evaluating the performance of land and agrarian reform in South Africa, it must be realised that by their nature, they are integrated with each other. For the purposes of this paper, not all the objectives will be discussed separately and may be clustered together. 
In looking at the first objective; namely, the promotion of incentives for raising production, policies such as the Comprehensive Agricultural Support Programme (2004) and the Land Redistribution for Agricultural Development Programme (2004) were put in place to facilitate the increase in agricultural production and output.

However, in the process of implementation, it needs to be realised that land reform is not restoring land back to individual owners, but to a community. This means that the land is communally owned and gives rise to a new type of agricultural producer. Ortmann and King (2006) look at small-scale farmers and ask whether cooperatives could facilitate an increase in agricultural production and thereby contribute to economic development.

But, according to Ortmann and King (2006), the success of co-operatives is dependent on internal and external strategies. Internal strategies that contribute to success are strong leadership for group action, competent managers who promote interests and identity, member participation in the policy-making process, as well as keeping stock, price and financial records. The traditional extension services in the agricultural sector need to be extended to include programmes that enable communities to successfully address the internal dynamics of successful agricultural production.

Otherwise, as Ortman and King pointed out, there will be a repeat of the co-operatives' failure in the former homelands of South Africa in which poor management, lack of training and conflict among members resulted in poor performance.

External strategies, on the other hand, include governmental intervention to create the economic, administrative and institutional environment in which these co-operatives can flourish. These interventions should reduce transaction, transportation and communication costs while enhancing access to input and output markets.

The Kwazulu-Natal Economic and Jobs Summit (2009) ${ }^{1}$ resolved that an important part of institutional support needed to incentivise agricultural production was to ensure the preferential procurement of agricultural goods and services from small agrarian producers by provincial and state institutions. This is because rural markets within, which the small-scale farmers operate, are limited by the buying power of the local economy, which is based on social grants received from the State.

Nyamande-Pitso (2004), in looking at the performance of small-scale agricultural producers in KwaZuluNatal, noted that accessing finance, markets, lack of transportation, accessing land for expansion, quality of produce and conflict within projects were the main constraints/challenges. These issues still remain relevant today due to the lack of capacity to facilitate timeous interventions.

In looking at the second objective, that of introducing costless methods of increasing production, there has been the introduction of the Agricultural Education and Training Policy aimed at empowering small-scale producers to be more knowledgeable in agricultural production. In this way, production can be raised without becoming capital intensive; i.e., timely ploughing, sowing, fertilisation, watering, etc.

But, what is needed according to the Summit (2009) is a diagnostic analysis of industry-related skills and the gap between the skills needed and those that exist. The training needs to be defined by these skills sets.

Authorities need to devise ways of recognising and valuing existing informal knowledge and skills of the workforce which can then be included in the formal training programmes. This will ensure that the appropriate knowledge for successful agricultural production will be implemented (Ibid).

The authorities need to resolve to adopt alternative farming systems, such as organic farming, hydroponics and permaculture. In addition, they need to look at allowing the diversification away from current commercial crops to alternative solutions that will provide the opportunity for the development of new markets supporting agricultural industries such as the production of essential oils and biofuels (Ibid).

\footnotetext{
${ }^{1}$ Roadmap to KwaZulu-Natal Economic Recovery aka The KwaZulu-Natal Economic and Jobs Summit, took place at Sibaya Casino and Entertainment Kingdom, uMdloti, Durban, 6 - 7 August, 2009.
} 
This overlaps with objective eight and the State's need to diversify agricultural production and to develop small and medium-based agro industries to provide further employment opportunities and markets.

One also needs to look at agriculture within the mainstream and international economy. Government needs to be sensitive to the implications of the World Trade Organisation's (WTO) negotiations on the domestic agriculture sector, especially in the light of subsidies paid to farmers in advanced industrialised economies and the impacts on domestic food security (Summit 2009).

The trade negotiations have resulted in the liberalisation of markets which has led to "greater volatility in agricultural prices. The result is a squeeze on farmers' margins that have prevented new entrants from being effective competitors and has led to alternative land uses becoming more attractive" (IGDP, 2010, p. 28). ${ }^{2}$

South Africa's trade policy has left the small-holder sector still burdened with socio-economic inequalities and increasing poverty levels with no benefits from international trade.

There must be the development of bankable investment projects in the agricultural sector, which results in the beneficiation of agricultural output, and that includes both large and small-scale producers. If these bankable projects are developed, according to McNellis (2009), Sovereign Wealth Funds (SWF), private equity (PE) and prudent international pension funds will provide funding for such agricultural projects as they are looking to diversify their portfolios to include more developing world agriculture in the form of commodity trading, investments in micro financing or the leasing/buying of developing world farmland.

Next, the process of achieving land redistribution has been addressed in policy through the Agricultural Broad-based Black Economic Empowerment Charter (AgriBEE, 2004). The target for land redistribution set by the AgriBEE was $30 \%$ of agricultural land to be distributed by 2014. Additional targets for the acquisition of agricultural land for black commercial farmers and participation in agro-industrialised business have also been set (Ibid).

However, the land distribution process is severely lagging behind the target with only $4 \%$ of transfers having been completed (Lebert, 2009). This underperformance was also noticed at the Summit in 2009, in which it was stated that contributing factors were slow bureaucracy, legal processes and measurement problems as the recording of transfers are complex. In addition, there are no mechanisms in place to facilitate the "willing buyer winning seller" opportunities, and in this regard, the Land Bank was seen as an essential role player who could intervene to accelerate this process (Hall, 2007).

Saunders (2009), in looking at lessons learned with regard to land reform in the sugar cane industry where only $8 \%$ of the $52 \%$ of the contested land has been redistributed, notes that land "needs to remain agriculturally productive and farmed according to best practice" as the cost of re-establishing sugar cane on dry-farming land is R15 000 per hectare.

This uncertainty and disorganised land reform, according to Mthethwa (2009), is endangering food security as productive land is lying abandoned with commercial farmers halting investment and leaving for neighbouring countries.

The focus has now shifted from simple land redistribution to ensuring that systems are in place to make productive use of land reform where it is under-utilised as well as coordinating the State and different interest groups to achieve the $30 \%$ target (Saunders, 2009).

Apart from land reform and claims settlements, there also needs to be tenure reform. The Communal Land Right Act 2004 (CLRA) was passed in February 2004, but this does not address the communal tenure reform which is the least evolved of land reforms. This could restrict the expansion of small-scale farmers and agricultural production. Nyamande-Pitso (2004) and Ortman and King (2006) indicated that a tenure rental system needed to be

${ }^{2}$ Agriculture, Forestry and Fisheries Integrated Growth and Development Plan 2011-2031. 
developed for communal land so that small producers could expand their agricultural production to enable them to compete with commercial farmers.

As already noted, agricultural support services are key in ensuring sustainable farmer settlement in South Africa and these need to be extended to the emerging small-scale farmers and co-operatives that are resulting from the land redistribution process. There needs to be investment in agricultural research, not only to increase competitiveness, but also in the application of appropriate technology needed to develop South African agriculture.

What follows is an amalgamation of objectives $(6,7,9)$ with regard to policy-making and implementation, the expansion of social services, as well as political and administrative capacity. The policy-making throughout has remained consistent, but as illustrated by the AgriBEE, the implementation has been poor. This has led to questions being asked from the Summit (2009) as to what has happened to AgriBEE as there seems to be no change in the make-up of the agri-business sector which still retains its historic composition.

The Comprehensive Rural Development Programme (CDRP) is an attempt to integrate agricultural development as well as expand social services. The CRDP's job creation model comprises three phases: 1) meeting basic human needs, such as shelter, water, sanitation, food and electricity, to name but a few; 2) development of enterprises, as well as critical infrastructure development (social, economic, ICT); and 3) the development of small, medium and micro industries (agri-processing, village markets and finance/credit facilities).

At present, this programme is limited to pilot projects in eight provinces and as a result, the majority of the rural areas remain unaffected by the programme as it has not yet been rolled out on a national basis.

It is imperative that government departments at the national and provincial level synchronise their efforts to implement land and agrarian reform. Maine et al (2007) suggest that the responsibility for land reform should be scaled down to a district level to deal with local demands so that it can be aligned with the integrated development plans of municipalities and that beneficiaries can receive adequate training and support at a local level.

In briefly looking at these nine objectives, we can clearly see that the land reform programme from 1993 until 2009 has not moved significantly towards redressing the inequalities that exist in access to land, thus the continued slow pace of land reform remains a constant constraint on the development of agricultural production for the future. If this land reform process is to contribute towards the sustainable development of agriculture in South Africa, then government needs to move from developing policy frameworks to actual implementation. This process of implementation requires a unified and coordinated effort. Government needs to ensure adequate research and the provision of support services to ensure that the land is used in a productive manner.

\section{THE WAY FORWARD AND BRAZILIAN MODEL}

The overall goal of land reform is to provide interventions necessary to achieve a balance between equity and transformation, growth and competitiveness and environmental sustainability.

In 2003, the Brazilian government developed a national plan for agrarian reform that was to address Brazil's unequal land redistribution that has restrained economic development. The historical land reform measures in this country have often been associated with deforestation and environmental degradation. As a result, new policies were introduced aimed at ecological land reform, which focuses on environmental and social restoration through land redistribution. In order to address these environmental concerns, the idea of 'ecological citizenship' was developed. This means that citizens were encouraged to behave in an environmentally sustainable manner.

"Ecological citizenship is conceptualized here as the discursive and active practice of relating the daily concerns of individual or family survival to that of the surrounding community and environmental space" (Wittman, 2010, p. 282). The practice of ecological citizenship evolves through changes in agricultural production, changes in environmental values, and the conservation of ecological reserve areas. 
Successive Brazilian governments have implemented plans for agrarian reform that have managed to integrate food production and environmental management. This has resulted in environmental objectives being incorporated into land reform programmes that provide livelihood and other opportunities for landless workers (Ibid).

Brazil's landless workers' movement (MST) emerged in the 1980s with one primary goal; namely, gaining access to land for the growing number of landless, estimated at over 10-million (Ibid). MST believes that the model of agricultural modernisation did not fit with the reorganisation of production sought by MST members who developed new strategies of cooperation to facilitate production and foster a sense of community in the new land reform settlements.

According to the 1998 constitution, members of the community had a fundamental right to land as a means of subsistence. Land needed to fulfill its function to society through legally defined productive and environmentally sustainable use. Under-utilised or environmentally degraded land is thus subject to expropriation for agrarian reform.

The Antonio Conselheiro Settlement in Mato Grosso negotiated the resettlement of its inhabitants on part of a large estate comprising $60 \%$ degraded pasture and $40 \%$ partially logged transitional forest. The Settlement was organised according to the movement principles which resulted in a settlement plan which designated $20 \%$ of the settlement area in permanent forest reserve, $15 \%$ in three areas of collective mixed-use reserve areas and $20 \%$ into family plots of 25-28 hectares each as individual environmental reserves.

The commitment of MST to ecological citizenship is most prominently evidenced by the adoption of agroecological production principles where traditional knowledge is blended with modern agricultural science to not only maintain food security, but genetic and cultural diversity. These methods, according to Kawell (2002), "are capable of increasing yields in marginal environments by over $100 \%$ while conserving soil fertility and biodiversity".

Within the mixed-use reserves, various agro-forestry systems have been introduced which involve coffee, banana, coconut and other tree crops. In addition, sales of organically-grown vegetables and the production of milk have been incorporated. Some farms produce solely for subsistence while sales of organic seeds, natural medicines, as well as agricultural inputs such as fertilisers and pesticides, are co-ordinated by MST on a national level.

Environmental education and agricultural extension are supported by MST which provides training in agroecological production methods as well as co-operative organisation of production in collaboration with universities and non-governmental organisations. Farming is no longer just a means of survival; rather, it is a space in which one can carry out socially responsible environmental action.

As a result, settlers engage in individual agro-ecological production and participate in the collective preservation of reserve areas because of their intrinsic environmental values. They exercise their rights to make decisions on how their areas can be economically developed and environmentally sustained.

The installation of the reserves and the physical features of the settlement provide a sustainable alternative to Brazil's conventional agricultural model and "offer one alternative for reducing pressures on the expanding agricultural frontier" (Ibid).

\section{CONCLUSION}

Much of the debate in South African land and agrarian reform has been balancing the redistribution of land against the loss of agricultural production. The focus has shifted from mere redistribution to ensuring that there are sufficient agricultural support services to create an enabling environment that will allow the new agricultural participants to be transformed into commercially viable producers. If this is achieved, this will contribute towards poverty alleviation and economic growth. 
The problem, however, is that the land redistribution process is following a slow and disorganised path, leaving communities in poverty with low rates of public and private sector investment, poor infrastructure and under-developed markets.

The conclusion is, therefore, that apart from the new policies, there has been no significant real change in the rural landscape since 1993.

Brazil, like South Africa, had to address the distribution of land which has constrained economic development. In order to avoid the environmental degradation caused by previous land reform initiatives. a new policy aimed at ecological land reform has been adopted. MST has encouraged the practice of ecological citizenship which has translated into changes of environmental values, conservation of reserves and changes in agricultural production. The concept of resource management has therefore been taken into the communities and is resulting in increasing agricultural output while following ecological principles. In addition, MST, which provides the training in agro-ecological production methods in conjunction with universities and non-governmental organisations, has reinforced the development of intrinsic environmental values within settlements.

Unfortunately, in South Africa there tends to be a disjuncture between non-governmental organisations, government and universities with respect to issues of land reform.

The idea of ecological citizenship has created a high degree of social cohesion and responsibility among the inhabitants of the settlements that is resulting in the use of the land in a sustainable and productive manner.

In the Brazilian constitution, land needs to be used in a productive and environmentally sustainable way and, if left unutilised or environmentally degraded, it is expropriated for agrarian reform. This may be a solution that South Africa might consider to ensure the scarce resources of arable land are secured for production.

\section{AUTHOR INFORMATION}

Jason Stratton Davis, is currently a lecturer in the Department of Public Management and Economics at the Durban University of Technology which is located in Durban South Africa. He lectures Economics to mainly first year students and has a keen interest economic teaching and learning. Apart from his research economic education, he has research interests in Development and Transportation Economics. E-mail: jasond@ dut.ac.za

\section{REFERENCES}

1. Agrawal, A. N. (1994). Indian Economy: Problems of Development and Planning (Vol. 19th Edition). New Delhi: Wiley Eastern Limited.

2. AgriBEE Broad-Based BlackEconomic Empowerment Framework for Agriculture. (July 2004). South African Department of Agriculture.

3. Agriculture, Forestry and Fisheries Integrated Growth and Development Plan 2011-2031. (September 2010). Retrieved. from http://www.nda.agric.za/doaDev/doc/IGDP/DAFF\%20DRAFT\%20SECTOR\%20IGDP\%20$\% 2013 \% 20$ Sep\%202010-1.pdf

4. Bernstein, H. (1992). Agrarian Reform in South Africa: Who? What? How?, paper to tenth Ruth First Memorial Colloquium, University of Western Cape.

5. Bernstein, H. (1996). How White Agriculture (Re)Positioned Itself For a New Economy. Critical Sociology, 22 (3), 9-36.

6. Comprehensive Rural Development Programme South Africa. (April 2010). Department of Rural Development and Land Reform.

7. Davis, J. (1993). Restructuring South African Agriculture The Free Marketers vs Redistributors. University of KwaZulu-Natal. (Unpublished: Honours thesis)

8. Department of Agriculture Budget and Strategic Plan 2008/9. (12 March 2008). Retrieved from http://www.pmg.org.za/report/20080312-department-agriculture-budget-and-strategic-plan-200809 
9. Drimie, S. (August 2002). The Impact of HIV/AIDS on Rural Households and Land Issues in Southern and Eastern Africa, A Background Paper Prepared for the Food and Agricultural Organization, Sub-Regional Office for Southern and Eastern Africa. Pretoria: Integrated Rural and Regional Development Human Sciences Research Council.

10. Erh-Cheng, H. (1983). The contribution of agriculture to economic growth. Washington, D.C.: World Bank.

11. Ferreira, N. (2010). Challenges for agricultural growth and development. Paper presented at the Agri SA Commodity and Farmer Development Conference. from http://www.docstoc.com/search/challenges-andperspectives-dot-(agricultural-development)

12. Gemmell, N. (Ed.). (1987). Surveys in Development Economics. Oxford: Blackwell.

13. Hall, R. (2007). Transforming rural South Africa? Taking stock of land reform. In L. Ntsebeza \& R. Hall (Eds.), The Land Question in South Africa: The Challenge of Transformation and Redistribution. Cape Town: HSRC Press.

14. Johnston, B. \& Mellor, J. W. (1961).The role of agriculture in economic development, American Economic Review, 51, 566 - 593.

15. Kawell, J. (2002). For an agriculture that doesn't get rid of farmers: An interview with Miguel Altieri. NACLA Report on the Americas, 35 (5), 29-34.

16. Kuznets, S. (1961). Economic Growth and the Contribution of Agriculture: Notes on Measurement. International Journal of Agrarian Affairs, 3, 59-75. Also in Eicher and Witts (eds)1964, 102-119.

17. Lebert, T. (2009). Rural Development in Post-Apartheid South Africa. COFISA Innovation in Rural Development Workshop. Johannesburg.

18. Lipton, M. (1977). South Africa: Two Agricultures? In F. Wilson, A. Kooy \& D. Hendrie (Eds.), Farm Labour in South Africa. Cape Town: David Phillip.

19. Lipton, M. (1993) The Role of the State in Restructuring South African Agriculture. In Lipton, M. \& Simkins, C. (Eds.) State and market in post -apartheid South Africa. Boulder, Westview Press.

20. McKenzie, C. (1993). Farmworker equity model mechanism to broaden the ownership base in agriculture. Land redistribution options conference proceedings, 12-15 October, 1993, Land and Agriculture Policy Centre, Johannesburg.

21. McNellis, P. E. (June 2009) Foreign Investment in Developing Country Agriculture - The Emerging Role of Private Sector Finance. FAO Commodity and Trade Policy Research Working Paper No. 28.

22. Meijerink, G. \& Roza, P. (April 2007).The role of agriculture in economic development. Markets, Chains and Sustainable Development Strategy and Policy Papers, No 5. Wageningen.

23. Mokhatla, P., Maine, N., \& Nell, W. T. (15 - 20 July, 2007). Sustainable Farmer Settlement in South Africa. Paper presented at the 16th International Farm Management Congress.

24. Mthethwa, B. (2009). Farms collapse as land reform fails. Sunday Times, 28 February, 2009.

25. Munnik, V. (1993/4) Land for the Fittest. Journal of Development \& the Environment, 14.

26. Nyamande-Pitso, A. (February 2004). The Evaluation of Empowerment Policies, Strategies and Performance within the Agricultural Sector: Kwazulu-Natal Province. Retrieved. from http://www.nda.agric.za/docs/agribee/Executive_summary.pdf.

27. Ortmann, G. F., \& King, R. P. (January 2006). Small-scale farmers in South Africa: Can agricultural cooperatives facilitate access to input and product markets? : Department of Applied Economics, College of Agricultural, Food and Environmental Sciences, University of Minnesota.

28. Reporter. (2008, October ). South African Agriculture. Retrieved 5 October, 2010, from http://www.southafrica.info/business/economy/sectors/agricultural-sector.htm

29. Roth, M., Dolny, H.,Wiebe, K. (1992). Employment, Efficiency and Land Markets in South Africa's Agricultural Sector: Opportunities for Land Policy Reform. Washington D.C.: The World Bank.

30. Saunders, C. (2009). Agricultural Value Chains. Paper presented at the KZN Economic Recovery Conference.

31. StatsSA. (17 February 2009). Agricultural Census (Census of Commercial Agriculture), 2007 Retrieved. from http://www.statssa.gov.za/publications/statsdownload.asp?PPN=P1102\&SCH=4534

32. Stiglitz, J. E., \& Yusuf, S. (Eds.). (2001). Rethinking the East Asian Miracle. Washington D.C.: The World Bank.

33. Strong backing for emerging farmers. (2010) South Africa.info http://www.southafrica.info/pls/procs/iac.page?p_t1=2780\&p_t3=10433

34. Timmer, P. C. (July 2005) Agriculture and Pro-poor Growth: An Asian Perspective, Working Paper No 63, Center for Global Development.

35. Wittman, H. W. (2010). AgrarianReform and Environment: Fostering Ecological Citizenship in Mato Grosso, Brazil. Canadian journal of Development Studies, 29(3-4), 281-298. 